\section{QUEER IN SOVIET AND POST-SOVIET RUSSIAN LITERATURE}

\section{KEY WORDS: Queer} sexuality, Homosexuality, Soviet regime, Post-Soviet Russia, Stalin, Reappearance, Glasnost.

\title{
Jyoti
}

Research Scholar, Centre of Russian Studies, SLL\&CS, Jawaharlal Nehru University, New Delhi-1 10067

This paper examines the reflection of queer sexuality in Russian literature and attempts to distinguish between Soviet and post-Soviet recurring narratives and trends. Its purpose is to give an overview of queer sexuality during Soviet and post-Soviet Russia. This paper reflects how this phenomenon was stifled during the Soviet era from the history of literature and again reappeared in post-Soviet Russia. It also explores the writers with their works who worked on this theme in the Soviet era and post-Soviet Russia. In addition, there are previously some notable works on this subject, for instance: "Out of the Blue: Russia's Hidden Gay Literature: An Anthology (1997) ed. by Kevin Moss, Introduction by Simon Karlinsky"; and "Russian Gay and Lesbian Literature by Brian James Baer, which was published in The Cambridge History of Gay and Lesbian Literature" (2014).

\section{QUEER ABOUT "SOVIET RUSSIA"}

The history and literature of queer sexuality have been way more unexplored and uncovered territory. It had led some of the few scholars from the west to examine this area of literature to claim that the institution of the Soviet Union in 1922 made homosexuality, abortion, and divorce legalized [Sarajeva, 2011].Nevertheless, the queer literature, which was flourishing before the formation of the Soviet Union, could not breathe more in Russian literature because the government did not embrace the cause of queer liberation. As years following the Bolshevik revolution suggested, writers writing on queer themes should work from home. The prominent writers on queer themes who stayed in Russia like Sophia Parnok, and Mikhail Kuzmin, could no longer print their works in the late 1920s. Writers like Mikhail Kuzmin and Sophia Parnok were shifted on translation to run their livelihood, often engaging works through which they might continue to show their thematic and aesthetic concerns. Kuzmin translated Shakespeare's Sonnets and Apulieus's "Golden Ass". One of Kuzmin's partner, translator Ivan Likhachev (1902-72), detained after Kuzmin's death [Baer, 201 1, p.31].

Several other writers who experimented with the topic of homosexuality included Nikolai Klyuev (1887-1937) and Sergei Yesenin (1895-1925), both belonged to the group of "Peasant poets" Esenin was a probable lover of Klyuev [Baer, 2014], who killed himself in 1925. Klyuev was sent to the Gulag camp, where Klyuev took his last breath. In 1933, when queer sexuality was made unlawful at the same time that abortion was criminalized. However, queer sexuality had previously escaped from Russian literature by this time.

Queer sexuality was obviously and intentionally prohibited by imposing law, and Socialism turned into the official guideline; any reference to homosexuality recorded was removed.The mass arrest took place in 1934, and the periodic crackdown for queer literature until "Glasnost" relaxed the control.There was minimal accessibility, on the off chance that anything that was printed between 1928 and Stalin's passing year shows that queer theme has composed any place no other than the privacy of one's own home.

"Those who were not imprisoned were silenced. The last hurrah of gay-themed literature in Soviet Russia was the miraculous publication in 1929 of Kuzmin's collection The Trout Breaks the Ice. This was 1 year after the publication of Konstantin Vaginov's novel Goat's Song (1928), which featured the gay character Kostya Rotikov" [Bear, 2015]. One-time lover of Marina Tsvetaeva (1892-1941), Sophia Parnok (1885-1933), also saw it more challenging to print in the 1920s. Her initial collection of verse, Poems (1916), written during her relationship with Tsvetaeva, was a real, non-decadent expression of lesbian desire. She was not able to publish her original work after 1928. Marina Tsvetaeva's poem "Podruga" ("Girlfriend") was not published until 1979, and was inspired by her relationship with Parnok. Poet Riurik Ivniev (1891-1981) also desisted to print his homoerotic poems in the Soviet era, and his prerevolutionary verse was never reprinted [Karlinsky, 1997].

Many elite intellectual gay writers, among emigres, took up residence in several urban cities worldwide. Poet Anatolii Steiger (1907-44) left for Paris, as did poet Marina Tsvetaeva; poet Valery Pereleshin (1913-92) immigrated first to China, then Brazil spent the rest of his life. Due to the fact that the Soviet diaspora was less homophobic than the Russian state, these poets could remain working and get venues to print their work. "Pereleshin's magnum opus Ariel (1976), which consists of 169 classical sonnets documenting an epistolary romance Pereleshin had with a man in Moscow, was first published in Germany" [Bear, 2015]. Gennadi Shmakov, a translator and balletomane, emigrated to New York City. Shmakov also brought new scholarly attention to Mikhail Kuzmin's work, which was forgotten in Soviet regime.

Vladimir Nabokov (1899-1977) - the most well-known novelist produced by Russian emigration, later an American writer, had many characters in many of his fictions, though he usually wrote of them sarcastically.

However, Stalin stifled and even tried to take out homosexuality from society. So much is obscure about Soviet regime politics, concerning queer people as a result of the secrecy that covered the Soviet era, and the fact that if Stalin or his allies did not like a specific individual or their way of life, they would edit or even purge them, all the while disposing of them from the vast majority of the historical records. In taking specific case studies of prominent figures in Russian culture before the Soviets came to control, we can perceive how the Soviets rethought Russian greats to fit in with the principle of Socialism. What is more, by taking a look at the way of life under the Soviets - the art, the film, and the writing - we can perceive how the Soviets utilized their impact to shape their own history by creating new art what preceded.

The two most notorious gay writers of Soviet Russia, Evgenii Kharitonov (1941-81) and Gennadii Trifonov (1945-2011) began to pen during the "Thaw period" following Khrushchev. Nevertheless, they were able to distribute their work only in underground literature (Samizdat). Kharitonov's unprinted collection of gay-themed stories, Under House Arrest, includes "One Boy's Story: How I Got Like That" and "The Stove," two of his most famous works. Trifonov was arrested and sent to Siberia for his unprinted collection of homoerotic verse to circulate privately entitled "Tblisi by Candlelight" in 1978, Trifonov sent an intrepid letter from jail to the journal Literaturnaya Gazeta, defending Italian gay activist Angelo Pezzano and advocating for gay rights. The letter was first published in the United States. 
The great fiction writer Evgenii Kharitonov, who died in 1981, was published to welcome in 1993. In Glasnost's period, gay unpublished works of past, such as Kuzmin and Leontiev, have been published; several gay periodicals came into the press; the foreign gay writers James Baldwin and Marcel Proust have been translated.

In the Soviet Russia, Igor Kon notes drastic changes only within late 1980s when Glasnost and Perestroika made it possible to appear the themes related to sexuality into public domain for discussions [Kon, 2010].

\section{QUEER ABOUT "POST-SOVIET RUSSIA"}

Following the disintegration of the USSR in 1991, freshly elected Boris Yeltsin's presidency indicated that the fate of homosexuals into literature might be great in consideration of the past by decriminalizing queer sexuality in post-Soviet Russia. "In 'One Hot Summer in St. Petersburg', the British author Duncan Fallowell also represents Russian (homo)sexuality in post-Soviet Russia as an erotically liberating alternative to Western-style gay identity. His novelistic travel account is the result of time spent in St. Petersburg in the early 1990s, when Russian society was undergoing rapid and dramatic changes. For Fallowell, who does not speak Russian, Russia is a libidinous place, a hallucinatory psychosexual landscape of seething passions, and Petersburg is an 'improbable dream city,' 'the sexiest town I've ever been in.'" [Bear, 2009, p.26].

Spontaneously, the signifying power of queerness in contemporary Russia, which was expanded in "cinema", "literature" and accordingly the "media" to debate not simply the "usual" concerns like femininity and masculinity, pleasure, decadence, vice and normalcy, but additionally such concerns as spirituality, aesthetics, individuality, victimhood. Unlike, the topic of visibility of queer sexuality in post-Soviet literature, press, and cinema, along with the maintained silence about Russian queers to "come out," has made queer sexuality as an open secret of post-Soviet Russian culture. The great secret as open, as Alan Sinfeld noted, "keeps a topic like homosexuality in the private sphere, but under surveillance, allowing it to hover on the edge of public visibility" [Sinfield, 1994, p.09].

Russian gays and lesbians were presently more visible than any other time. "With the exception of Igor Kon, there were few authoritative scholarly voices in Russia who could make sense of the cacophony of views on homosexuality presented in Russia at that time. To make matters worse, homosexuality became a popular theme in writing by non-gay authors, where it was often used to symbolize the chaos of post-Soviet life. In addition, works of popular psychiatry, such as Dilia Enikeeva's Sexual Pathology and Gays and Lesbians, presented "nontraditional" love as a trendy, Western-inspired phenomenon and warned of the danger to Russia's youth from semi-hidden gay cabals in the Russian entertainment industry and in the highest political circles."[Baer, 2014]

Initial post-Soviet homosexual fiction reflected an everlasting ambivalence on Russian homosexuality as a native phenomenon. One of the earliest editions of post-Soviet gay fiction was the collection "The Other". As the title insinuates, all the stories involve romantic encounters with west men, strengthening the favored view that queer sexuality was essentially un-Russian. Likewise, Works by Russian gay authors, like the novels "Who Resembles the Harlequin" (1997), by Dmitry Bushuev, "And a Finn" (1997), by Aleksandr Ilyanen, and the drama "Slingshot" (1989), by Nikolai Koliada, staged in Russia, varied from the works by non-gay authors, like "Around Dupont Circle" (1996) by Vasilii Aksenov, Liudmila Ulitskaia's "Darling" (2001), and the drama "My Gay Friend" (2003), by Ekaterina Kovaleva [Baer, 2014].

Most of non-queer writers propagated the long-standing relationship of homosexuality with tragedy, aestheticism, and spirituality. Best-selling writer Grigorii Chkhartishvili contributed a long work of nonfiction, The Writer and Suicide, that introduced a separate chapter on gay authors, he affirmed, "same sex love, unlike normal love does not hold the promise of a happy ending of the they lived happily ever after variety" [Baer, 2014]. Post-Soviet literary writer, present the fate of the queer as intensely tragic. A minimum of one gay character meets an untimely, if not violent, death in all of those works.

This newly imposed "homosexual propaganda law" made the chief subjects of the works of openly gay writers concerning coming to terms with own sexuality as there are various established and developing poets and writers (Sergei Rybikov, Alexander Ilyanen, Dmitry Bushuev, Alexander Shatalov, Iaroslav Mogutin, Dmitry Kuzmin).

\section{REFERENCES:}

[1] Baer, B. (2009). Other Russias: Homosexuality and The Crisis of Post-Soviet Identity. Springer.

[2] Baer, B. J. (2011). Translating Queer Texts in Soviet Russia: A Case Study in Productive Censorship. Translation Studies, 4(1), 21-40.

[3] Baer, B. J. (2014). Russian Gay and Lesbian Literature. The Cambridge History of Gay and Lesbian Literature, 421-437.

[4] Baer, B.J. (2015). Sexual Minorities in Modern Russia. In J.D. B.T.-I.E. of the S. \& B. S. (Second E. Wright (Ed.), International Encyclopedia of the Social \& Behavioral Sciences: Second Edition (pp. 740-743). Elsevier. https://doi.org/10.1016/B978-0-08-097086-8.10218-1

[5] Karlinsky, S. (1997). Introduction: Russia's Gay Literature and History. MOSS, $\operatorname{Kevin}(E d), 15-29$.

[6] Kon, I. S. (2010). Klubnichka na berezke: Seksualnaia kultura v Rossii/Igor Kon.-[3- izd.,ispr.i dop.]. .:Vremia.

[7] Sarajeva, K. (2011). Lesbian Lives: Sexuality, Space and Subculture in Moscow. Acta Universitatis Stockholmiensis.

[8] Sinfield, A. (1994). The Wilde Century: effeminacy, OscarWilde, and The Queer Moment. Columbia University Press. 